\title{
Théophile de Viau, Les Amours tragiques de Pyrame et Thisbé
}

\section{Laura Rescia}

\section{Q OpenEdition}

1 Journals

\section{Edizione digitale}

URL: http://journals.openedition.org/studifrancesi/5308

DOI: 10.4000/studifrancesi.5308

ISSN: 2421-5856

\section{Editore}

Rosenberg \& Sellier

\section{Edizione cartacea}

Data di pubblicazione: 1 dicembre 2016

Paginazione: 521-522

ISSN: 0039-2944

\section{Notizia bibliografica digitale}

Laura Rescia, «Théophile de Viau, Les Amours tragiques de Pyrame et Thisbé », Studi Francesi [Online], 180 (LX | III) | 2016, online dal 01 janvier 2017, consultato il 18 septembre 2020. URL : http:// journals.openedition.org/studifrancesi/5308; DOI : https://doi.org/10.4000/studifrancesi.5308

Questo documento è stato generato automaticamente il 18 settembre 2020.

\section{(c) (i) (9)}

Studi Francesi è distribuita con Licenza Creative Commons Attribuzione - Non commerciale - Non opere derivate 4.0 Internazionale. 


\title{
Théophile de Viau, Les Amours tragiques de Pyrame et Thisbé
}

\author{
Laura Rescia
}

\section{NOTIZIA}

THÉOPHILE DE VIAU, Les Amours tragiques de Pyrame et Thisbé, présentation par Bénédicte Louvat-Molozet et Guillaume Peureux, Paris, GF Flammarion, 2015, 185 pp.

1 Esce per la prima volta in edizione tascabile la famosa tragedia di Théophile de Viau, di cui disponevamo di numerose e valide edizioni (a cura di G. Saba, fin dal 1967, ristampata dai Classiques Garnier nel 2014; di J. Schérer nel volume della Pléiade dedicato al teatro del xvII secolo, apparso nel 1975; di G. Forestier, per le edizioni del Théâtre national de Strasbourg, pubblicata nel 1992), ma nessuna in formato agevole, economico e utile ai fini didattici. Il testo, ripreso dall'editio princeps del 1623 ed emendato tramite la collazione delle edizioni del 1626 e 1632, è preceduto da una sintetica introduzione, dedicata al mito di Piramo e Tisbe e all'estetica teatrale di Viau, e seguito da un dossier tematico, una buona bibliografia, una essenziale cronologia storico-letteraria (1572-1635) e un glossario. 